\title{
Basic Needs and the Division of Labour
}

\author{
GUY STANDING*
}

\begin{abstract}
In the basic needs literature remarkably little critical attention has been devoted to the role of labour. In this paper the prevailing dominant approach to the notion of basic needs and the basic needs 'strategy' of development is criticised, primarily for neglecting human labour as a central, integrating life activity. It is argued that two alternative 'visions' of development exist which imply different perspectives on 'employment'. The paper then considers what should be the crucial elements in the nature and division of labour for a humanistic strategy of development, and concludes by proposing a reorientation of employment data collection.
\end{abstract}

\section{INTRODUCTION}

It is a healthy trend that in recent years far more attention has been paid to the real objectives of economic development than was the case when development was equated with economic growth rates. The trend still has some way to go, but the inadequacy of focusing solely on rapid economic growth or industrialization to the neglect of the immediacy of inequality and attendant poverty has now been accepted by the majority of development economists. The doctrine of "functional inequality", which, for example, some saw as epitomizing Pakistan's planning between 1947 and 1968 , has long ceased to be conventional wisdom. ${ }^{1}$

The shift to "redistribution with growth" was a move in the direction of focusing on equity considerations, recognising that the pursuit of greater economic equality was a legitimate and desirable objective in itself. But that approach was actually little more than a modified form of a growth-oriented strategy, leaving it unclear whether the redistribution was expected to take place before, during, or after any particular increment of economic growth, and if after, how long after. It was also somewhat unclear what besides income was to be redistributed, and, above all, it was unsatisfactory because it did not focus specifically on mass poverty in the countries concerned.

*The author is Director-General of the Population and Labour Policies Branch, Employment and Development Department, ILO, Geneva, Switzerland.

${ }^{1}$ For the periodisation in Pakistan, see [3, pp. $\left.58-93\right]$. 
Increasingly, the focus shifted to the need to tackle poverty directly and the need to improve the income of certain poverty-stricken groups. The ILO's World Employment Programme, having initially concentrated on measures designed to increase what was described as "productive employment", became absorbed by the objective of stimulating the incomes of the poor, to show that the liberation of the "informal sector" would be a major means of stimulating economic growth while improving the incomes of the poor and reducing income inequalities. ${ }^{2}$ However, reservations about the scope for generating employment that whould rapidly reduce poverty helped crystallise thinking around the notion of "basic needs", which became a central concern of the World Employment Conference in 1976 [15]. That conjuncture was rather ironic, for quite remarkably, despite all the attention basic needs has received since that Conference, the inter-relations between employment and basic human needs have been largely ignored.

"Basic needs" is or should be a philosophical concept, a notion to be used as an organising framework for the analysis of poverty, deprivation, and social justice. Yet the critical content of the concept of basic needs has been largely usurped, so much so that it is a serious question whether it has become a progressive or a reactionary shift of focus. Instead of being a tool for a direct challenge to the so-called development strategies, it has been linked to them, transformed from a challenging slogan to what can be described realistically as a "technocratic" notion that embraces the provision of some minimal level of nutrition, clothing, shelter, schooling, and health services, from which it has been relatively easy to derive a set of liberal policy prescriptions - invest in schools, in hospitals, in housing construction, and so on. ${ }^{3}$ Usually, adherents of this approach have been careful to dutifully preface their analyses by noting the need to "increase the socio-economic participation of the population" and to take account of what are somewhat nebulously called "non-material needs". ${ }^{4}$ Some have not even bothered to do that. ${ }^{5}$ But even when they have acknowledged such non-material elements, it is hard to escape the conclusion that this part of the prognosis has amounted to very little more than mild gestures, for the underlying logic of the implicit tokenism has not been explored.

In fact, in the development literature the emphasis has been placed on what has been called a 'core' set of basic needs, usually taken to comprise nutrition, health, education, and shelter [6, pp. 3.3.2 and $1-10]$. Again, many of those who have concentrated attention on such core aspects of life have noted that basic needs

${ }^{2}$ After studies in Sri Lanka, Colombia, and Iran, the emphasis on the informal sector crystallised in a report on Kenya [16]. Other large-scale studies were conducted in the Philippines and the Sudan, gradually changing in character in the cases of Tanzania, Zambia, Somalia and Portugal.

${ }_{4}^{3}$ For a critique of the "technocratic approach" to basic needs, see [35].

${ }_{5}^{4}$ For cogent statements of this view, see $[10]$ and $[28$, pp. $445-460]$.

${ }^{5}$ See, for instance, [32, pp. $\left.11-28\right]$ and [31]. encompass much more than the core items. But, having made this ritual bow, they have proceeded to consider means of satisfying certain minimum standards of the core needs. They have then set targets and tried to outline policies that would achieve those specific targets by some specific date. There is an advantage in doing this for such scholars, in that it makes analysis and "policy formulation" so much more tractable. But, as argued later, such an advantage conceals an ideological sleight of hand. Moreover, a danger inherent in this approach is that certain elements become basic needs while other aspects of life are treated as mere "means to an end". That is why it was ironic that the "enthronement" of basic needs came in the ILO's World Employment Conference, for despite the occasional statement to the contrary in the Conference's report, that has been the fate reserved for employment - work is seen as a mere necessity, to be done to acquire the means of satisfying basic needs.

Yet, the distinction between ends and means is an essentially arbitrary one, which should be shelved as misleading. This is so for several reasons. Firstly, to take a few core needs out of their wider social context is objectionable if only because doing so abstracts from the social reality of poverty, inequality, exploitation, and economic insecurity. Poverty is more than a matter of a deficiency of goods and services for a certain proportion of the population: it is also fundamentally a question of the relationships between people and socio-economic groups. Indeed, it involves the combination of absolute and relative deprivations. Furthermore, logically none of the core needs can be defined as ends in themselves any more than can any other aspect of human existence. We need food to survive. As such, it is a means to an end; but the amount of food we require depends on activity, for example, while the notion of "survival" covers a wide range of conditions of existence. We could survive by sitting or lying down most of the time, which would reduce energy expenditure and thus the desired or necessary calorific intake. In many places, this is precisely how people have responded to adversity. Nutrition is clearly a means to the end of survival, but for how long or as what is unclear. This may seem pedantic, but it serves to highlight the point that the essential human need is that of survival, which encompasses not merely physical survival but the steady extension of human creativity, the opportunity to pursue individual or what are sometimes called "free needs", a point to which we will return.

\section{THE TECHNOCRATIC APPROACH}

Despite occasional denials, the dominant theme emanating from the conceptualization of basic needs since 1976 has been "count, cost, and deliver". Though a search of the literature should make one doubt whether there is such a generalisable notion, "the basic needs approach" was given what amounted to a mantle of respectability by the World Bank's adoption of the concept. Subsequently, it is scarcely surprising that the terms of the debate have assumed a rather conservative character. Thus, to give just one example, a prominent Bank economist explicitly rejected the 
necessity of political change, 'claiming with truly remarkable intuition, "It is evident that a wide variety of political regimes have satisfied basic needs within a relatively short time" [36, p. 142]. It is that sort of statement that reveals the sleight of hand involved in making a few "core material" needs into basic needs, for it effectively bolsters a politically conservative ideology.

The resultant dominant approach to the anslysis of basic needs has had a predictable effect on the perception of appropriate policies. For it has stimulated a search for selective, piecemeal interventions that have often been little more than palliatives to preserve the socio-economic structure, which in reality has been the fundamental cause of the perceived poverty. Thus there has been discussion of a basic-needs approach to tree-cutting and a basic-needs approach to road construction - which in both cases amounts to little more than advocacy of a labour-intensive technology, the presumption being that that would give poorer groups of workers greater opportunities to earn some sort of income. In the same vein, some authors have conceived of "basic needs activities" [11, Chap. 4]. With such an approach, sceptics have been able to draw the conclusion that globally the basic-needs strategy implies a more rigid international division of labour, whereby the low-income countries would continue to concentrate on primary commodities and those products involving low-yielding, labour-intensive techniques of production, while the affluent industrialized countries retain the preserve of the technological frontiers.

In its various guises the technocratic approach to basic needs can give rise to some peculiar lines of reasoning. One could list a large number of examples, but it might be instructive to cite three cases only, all of which try to make a virtue of eschewing broader changes in social relationships and all of which involve distinguished development economists. The first is a fairly detailed analysis of basic needs target-setting in Pakistan conducted by Burki, Hicks, and Haq in the course of which they state unequivocally that their strategy does not require any political change $[5] .^{6}$

They discuss various so-called core needs and couch the analysis in terms of public expenditure requirements. In the course of their discussion they claim that "the country appears to be very close to solving the problem of nutrition" [5, p. 2]. They base this on the claim that "some 19 million people consume less than the 85 per cent of the recommended dietary allowance for calories" $[5, \mathrm{p} .6]$. If that is close to solution, one wonders what would have been the conclusion if there was a figure of, say, 10 million. However, that pedantic point aside, they proceed to assert that the figure implies a need for an increase of 700,000 tons of food grain, though it is not explained how you can derive such an estimate from a "less than" statement,

${ }^{6}$ Note in particular paragraph 51 , p. 27 , where in the midst of other such statements it is claimed, "The implementation of the strategy is not even predicated on capturing the incomes of the wealthier classes through heavy taxation", let alone "a drastic land reform" or "a drastic reduction of land ceilings" or "elimination of absentee landlords". Truly a world made for Dr. Pangloss. since most people would assume that it all depends on how much less than the 85 percent the actual figure was. They then put all this into perspective by noting that "a 6 per cent increase in Pakistan's present food grain output would solve the nutri tional problem" [5. p. 6]. The reader is induced to feel optimistic. But then the caveats are noted, little clauses that make the critical mind more than a trifle concerned about the whole exercise. First, the authors recognise that the main cause of what should surely be described as substantial malnutrition is "inequality of income distribution" - though almost certainly they should have attributed it primarily to inequality of access to the means of production and to the structure of production. Secondly, they claim that the 6 percent output increase could solve the problem "if all of it could be directed towards the underprivileged groups" [5, p. 6; italics added]. But how is all that to be achieved? The suggested answer is veiled in terms of a "small farmer strategy", the Government providing various delivery services. They candidly admit that, given the size of small holdings, some land consolidation would be necessary, though they do not mention that historically land consolidation has hardly been the best prescription for reducing malnutrition and poverty quickly. To be fair, they tag on that a delivery service programme "may provide the incentives the farmers need to organise themselves into co-operative units" $[5, \mathrm{p} .8$; italics added]. But the readers are doomed to disappointment if they search for an elaboration of this not insignificant point. How can this amount to a basic-needs strategy of development if the analysis leaves off at the very point where one must pose difficult strategic questions?

In the same vein, later we read that the problem of malnourishment of children is "sociological": this is the pretext for curtailing the analysis. Actually the problem of malnourishment is fundamentally due to a lack of available food and citing the relative rates of mortality of different groups does not entitle the analysts to explain the problem away as "sociological" (whatever that means). In sum, one cannot help concluding that such so-called analysis actually lacks an economic analysis.

The second example illustrates the danger of divorcing the analysis of poverty policies from basic human needs. Irma Adelman gets herself into a terribly uncomfortable position that ill becomes a liberal spirit - advocating redistribution at the same time as weeping crocodile tears for democracy, recommending the sort of land reform which would "regrettably appear to require restriction of participation and concentration of power in an autocratic ruler" $[1, \mathrm{p} .14]$. This is scarcely a creditable position to adopt if the pursuit of basic human needs is the objective of development strategies.

The third example is a recent discussion of policy options for achieving "more egalitarian" development and "satisfying basic needs". At least in the first part of their paper Griffin and James, in discussing the likely consequences for poverty of a redistribution of income, implicitly assume that a redistribution would be done by means of transfer payments. This implies that the structure of production itself would not be affected directly. Then, in analysing short-run supply responses to a 
change in income distribution they draw on estimates of short-run elasticities of supply of food grains, which have been small, to deduce that "a massive redistribution in favour of the poor would lead to roughly a doubling of the prices of wage goods, or more" [12, p. 253; italics added]. The authors do not tell us the basis for these alarming conclusions, though as they do not specify what is implied by "a massive redistribution" one is entitled to feel that such "fancy" calculations are merely provocative. In any case they ignore the possibility that income redistribution could be achieved by altering the structure and nature of production and the social relations underlying it. And they also deduce their conclusions about a massive redistribution from short-run price elasticities based on marginal changes in demand conditions, a suspect exercise in itself.

Having concluded that redistribution would lead to massive price increases, the authors a few pages later tag on a section stating that there are a number of ways of affecting income distribution. Price policy is considered, the drawbacks listed. Mini mum wage policies are dismissed with a few "on the one hand" this and "on the other hand" that remarks. Employment creation is presented somewhat strangely as being dependent on "public works" programmes. With reference to a transport programme, it is noted, "It is no simple matter, however, to implement programmes of this type" $[12$, p. 260]. The authors make a few favourable remarks about the East Pakistan Works Programmes started in 1962, but as they draw no general conclusions, it has to be presumed that they do not regard public works programmes and thus, on their logic, employment creation - as an effective means of redistributing income.

The short section devoted to income transfers argues that to be successful they must be accompanied by a "redistribution of assets". Then a couple of pages later it is stated, somewhat mysteriously, that "in most cases asset redistribution will have to be accompanied by other measures ...." This type of discussion may be intellectually rewarding but in its discursive review it gives the impression that governments are impartial arbiters with "menus of policies" from which they can and will choose. In short, it assumes a liberal theory of the State. This is epitomized by the concluding section of what is a good example of this genre of analysis. This presents what is grandiosely described as "a policy matrix" and the authors reach a fitting climax when we are told that "in practice a variety of measures to change the distribution of income and wealth. will have to be adopted, either jointly or sequentially" $[12$, p. 265]. Such revealing eclecticism is the Achilles heel of the populist approach to underdevelopment.

All these difficulties arise primarily because the concept of basic needs has not been integrated into the theoretical analysis of the process of underdevelopment, or seen in the context of the causes and social functions of poverty and inequality. Unless these are understood reasonably well, even genuinely redistributive measures are likely to be self-defeating.
The technocratic approach should be rejected, though the concept of basic human needs should always be the focus of social and economic analysis. The debate should move away from defining core needs or "bundles of basic needs", and even further away from setting basic-needs "targets", "interim targets", "basic needs income levels", and the like. For they shift attention away from the social and economic structure of production and distribution. They therefore tend to lead to a set of liberal policy prescriptions that are Utopian or unrealistic simply because they are typically divorced from social reality. What is the practical use of setting targets - often in splendid detail - if such targets have no possibility of being realised because they are incompatible with the interests of the dominant class or classes of the society in question? And because the practice of target-setting tends to lead to essentially arbitrary standards and dividing lines - more than occasionally raising the spectre of poverty datum lines - it is an approach that is easily ridiculed as unrelated to social reality or, if the targets are selected to be feasible with the existing social structure and political regime, merely seen as a convenient device for preserving the status quo.

In short, the approach to basic needs represented by the identification of core needs and targets is a false start. The alternative and more promising approach involves facing the essentially philosophical issue of what constitutes human needs. Poverty, it must be constantly emphasised, is more than a shortage of goods; it is as much a reflection of the relations between people, people as individuals and people as members of different classes and social groups. Wherever they live, people define their basic needs in the course of their soical existence, and their perceived needs are shaped by the combination of the economic structure and their social and economic status within that structure. Consequently one cannot escape from the fundamentally political nature of poverty and inequality. This approach can best be considered in terms of the prevailing social relations of production and distribution, the forms of exploitation corresponding to those social relations, and the nature of employment.

\section{BASIC NEEDS AND SOCIAL RELATIONS OF PRODUCTION}

"The law of the Emperor yields to the custom of the village." (Vietnamese proverb)

The social relations of production determine not only how much economic surplus is produced by the direct producers, those actually producing goods and services, but the distribution of that surplus. As such, it is unrealistic to conceive of the "satisfaction of basic needs" in societies based on the systematic exploitation and deprivation of one class by another, where that involves the systematic denial of certain rights and needs of the dominated groups, and where classes are defined by their relations to the production process.

For that reason, it is essential to make an analytical distinction between human needs and what can be called immediate needs. The former are distinguished by their 
universality, being needs that reflect the human capacity for a limitless extension of imagination, creativity, and manual and mental abilities. Humanity is distinguished from other species by the ability to transform the environment in predetermined ways and to create and extend human potential through increasing the quantity and quality of needs.

In contrast, immediate needs are created in society and reflect the social structure. It is a basic axiom of social theory that, as Rawls put it, "The economic system is not only an institutional device for satisfying existing wants and needs but a way of creating and fashioning wants in the future. How men work together now to satisfy their present desires affects the desired they will have later on, the kind of persons they will be " $[26$, p. 259]. Rawls was correct as far as he went, but in addition the needs that emerge in a class-based society cannot be validly described as basic human needs because they reflect the alienated needs of a divisive system of production and exchange. Landlords, peasants, wage workers, capitalists, and rentiers all determine their immediate needs by relation to the group to which they belong. And as each group only exists in relation to some other group, each pursues its immediate needs in implicit conflict with other groups. As such, the demise of such conflicts represents a necessary condition for the pursuit of human needs. To give just one, albeit graphic, example: Would it be meaningful to contemplate a basicneeds development strategy for India that left untouched social relations by which possibly 5 million rural workers were in some sort of bonded labour? ${ }^{7}$

To analyse the extent of relative and absolute poverty in any particular society, and thereby to assess trends, it is essential to identify the means by which the poor are exploited and oppressed. This must go beyond measures of income inequality and also beyond the ownership or possession of means of production, notably land. Both of these are important indicators of the extent of relative and absolute poverty, and in many countries in South and South-East Asia there is evidence that, for example, the extent of landlessness has grown in recent years. Where such developments have occurred they are almost surely indicative of worsening relative and absolute poverty. But measures of income inequality may well be misleading indices of the real social and economic inequalities, for the poor may face heavy obligations or be indirectly exploited by a wide range of unfavourable terms of trade between the goods produced by the poor and the goods they need for consumption.

In many societies quasi-feudal relationships of production have enabled landlords to appropriate large proportions of peasant produce and incomes, both directly in the form of money rent, labour services, rent in kind, and debt bondage, and indirectly through the manipulation of prices or through various other market mecha-

${ }^{7}$ This is the lower bound of the estimate based on the twenty-seventh round of the National Sample Survey. Another study suggested a figure of about 2 million, though of course the analy tical point does not rest on numbers. See [9] nisms ${ }^{8}$ Any surplus not creamed off in rent has typically been extracted by usury, money-lenders in some areas lending to desperate villagers at rates of interest of 50 percent or more. In such circumstances any viable basic-needs strategy must be concerned primarily with suppressing such exploitative relationships. With or without foreign aid, a government policy of correcting the worst forms of poverty by income transfers or even by the provision of subsidised items of subsistence would not be very effective. They would continue if landlords, money-lenders, and their ilk retained the power to appropriate as much surplus as served their long-term interest - that of preserving as much inequality as was consistent with the maintenance of the class structure and the passive acquiescence of the exploited. Thus if a more effective "delivery service" of some basic item of subsistence was provided without any change in the village power structure, it could be safely predicted that very shortly exploitative screws would be tightened so that the peasants were just as impoverished as they were beforehand. As one sage put it, the whole filthy story would start again. Moreover, once a social nexus of traditional obligations and rights were disturbed, the subsequent impoverishment would tend to be increased by correspondingly greater insecurity. ${ }^{9}$

Moreover, it cannot be overlooked that the pattern of inequality associated with the social structure and labour relations of production are almost certainly reproduced in the administrative and political spheres. If this is recognised it makes the claim that political change is not necessary for the attainment of basic needs at most wishful thinking.

Compared with the normal "delivery service" approach, the focus on social relations of production and distribution as the key to the nature and extent of inequality, poverty, and exploitation leads to a quite different perspective for a whole range of basic human needs. Take, for example, food and nutritional requirements. It is well established that individual requirements for calories and protein are related not only to body weight and height but to activity. A man or woman forced to work eight or nine hours a day doing heavy manual labour with little rest would require compensatory calories. The claim that the requisite extra calorific intake is a basic need would be absurd. A basic-needs strategy should be concerned with eradicating the conditions that make a person of given body weight and height need above noraml calorific intake. This simple example highlights the fact that the analytical perspective one takes helps identify the appropriate intervention point, or

${ }^{8}$ In the light of the claim that 'basic needs' could be satisfied in Pakistan without the changes ruled out by Burki et al. (see footnote 6 above), the interested reader should read the moving a exploitation and oppression in the Attock District [2]

${ }^{9}$ Most low-income communities survive by means of diverse forms of 'structured reciprocities' which provide a necessary degree of security against adversity. It is these which development' largely disrupts. For a provocative account, see [27]. 
more likely exposes inadequate intervention points. Without taking account of the labour relationships, the recommended policy might entail redistributing food according to the individual's and group's immediate needs. The emphasis would thus be on the delivery system and, perhaps, the redistribution of purchasing power. In fact, however, efficiency and equity would be better served by tackling the labour relations directly. But, of course, compared with appeals for improved delivery services, that is a much more sensitive political issue, since it goes to the heart of the economic base of the society.

Let us take another example. Most would agree that education is a basic human need, and indeed one can argue that it is the human need. Yet in what way is that need to be defined? In a pre-capitalist economy consisting of a handful of powerful landlords and a majority of impoverished peasants it would be a senseless exercise to define educational needs in any quantitative manner. That is if such needs are considered immediate needs. Indeed, formal schooling might be dysfunctional for typical villagers, adversely affecting their ability to survive in the economic environment where the accumulated daily experience of merely surviving and the steady assimilation to adult life through work would be rather more important.

A policy of providing more schooling facilities would have little effect if child labour was essential to the daily survival of the rural poor, particularly during certain times of the agricultural calendar. Many analysts of basic-needs strategies seem to neglect such simple facts of life. It is unhelpful to consider the provision of schooling facilities in any quantitative, financial terms - as is common - without first analysing the functional or dysfunctional role of schooling in the social context in question [29, pp. $75-78]$. The provision of more buildings, "more qualified" staff, even free school meals and the like, may all be desirable in themselves and may well have some small effect on school enrolment and attendance. But they are more likely to be costly and inefficient on their own terms if the poor see that schooling has little immediate value to their chances of meeting their subsistence requirements or if families have to rely on the work input of children. Indeed, it is conceivable that schooling could disrupt the village economy if it was successful in drawing large proportions of the village children into school at times when family labour was most urgently required. In other cases, the provision of school facilities is likely to be unsuccessful because landlords exact labour services from peasant families on the supposition that children of those families are contributing either directly or indirectly. Without an analysis of the underlying social relationships, policy prognosis in such circumstances is almost bound to be erroneous. Similarly, in many countries efforts to spread literacy have been impeded by the fact that a great many of the poor have little opportunity and little daily need to use and develop their literacy; one consequence has been a widespread incidence of "relapsed literacy".

None of this should be taken as implying that somehow education is not a basic human need. But it is essential to distinguish between the human need for education and the immediate needs of individuals and groups in specific social and economic contexts. And economists surveying developments in the educational field should always ponder its role in those contexts. Indeed, many would argue that formal schooling for the majority of the poor, in industrialized and in low-income countries, has not been designed or utilised to serve the basic human needs of the participants, but has been geared to create a set of appropriate attitudes to authority and a set of usable skills that serve the interests of employers and others, while underdeveloping creative and imaginative capacities, a point to which we will return.

In the light of the underlying social relations of exploitation and domination, what are the likely effects of the most commonly proposed basic-needs policies in a low-income, mainly agrarian economy? A major theme of "development econom ics" in recent years has been the need to reorient rural development projects to "target groups". ${ }^{10}$ If it was observed that x percent of the rural population was suffering from a lack of food, various non-radical policies could and probably would be considered, where non-radical means a policy that did not involve changes in the social relations of production. These might entail direct food aid or transfers, a rural credit policy directed at small-scale farmers, a shift in the pattern of investment, or a shift in the agricultural terms of trade (between basic foodstuffs and other commodities). All these policies suffer from one drawback in that by leaving the social structure and thus the potential for exploitation virtually intact they are likely to have only short-term benefits for the poor, if any, until such time as the land lords or other dominant groups can devise new forms of exploitation. Indeed, perhaps perversely, if such transfers are done without any expense to the dominant rural groups they may merely facilitate a higher level of exploitation and greater inequalities. Altering the terms of trade may well stimulate food production, but that is most likely to be done by the landlord farmers who have often responded to such changes by evicting tenants, cultivating a greater proportion of the lands they own or control, and making labour-saving innovations. In other words, such policies tend to favour those who have the capacity and resources over those who have relatively little of either, and they are therefore almost certainly conducive to socio-economic polarisation.

Recognising the limitations of such policies, many of those who espouse socalled basic-needs strategies place considerable faith in what might be described as the semi-radical policy of land reform, often citing the cases of Taiwan and South Korea where redistributive land reform preceded a long period of economic growth and industrialization. Certainly, land reform has tended to accelerate capital accumulation, thereby stimulating economic growth. But in most cases of land reform it has not been the poor who have benefited. Typically there has been mass ejection of tenants, a consolidation of farm units by capitalist farmers, and a general

\footnotetext{
${ }^{10}$ See, for instance, $[14]$. For a general critique, see [19, pp. $\left.99-114\right]$.
} 
growth of landlessness and rural emigration [25, pp. $747-763]$. In some cases land reform has been introduced as a palliative to preserve the social control of specific groups and in some cases to augment capital accumulation by reducing the cost of food so that the wages of industrial urban workers can be kept down. Paradoxically, even when land reform has been introduced in the interests of the rural poor the result has often been a deterioration in the living standards of the rural poor.

For instance, one of the earliest land reforms, the Ejido in Mexico, which created a whole class of small-scale farmers, seems to have had the perverse effect of leading to the substitution of landlords by "capital lords", or, as one author has described the process, a replacement of "patrons-in-land" by "patrons-in-capital" [24, pp. $239-240]$. Similarly, in Iraq in 1964 the sheikhs, having had their land expropriated, still managed to take up to 90 percent of the crops of former tribesmen in payment as rent for mechanical equipment [18, p. 398]. In Pakistan and India, as in many other countries, partial land reforms setting ceilings on landholdings have been widely circumvented by numerous devices, the most notable being intra-family transfers and the establishment of essentially bogus co-operatives, as in parts of the Indian Punjab where it is common to see large corn-fields containing conspicuously placed "orchard trees" and little "places of worship".

The point about land reform that should be emphasised above all is that by itself it may either increase the extent of "peasantisation" or, if manipulated by commercial interests, the extent of "proletarianisation" [25]. In either case, it is scarcely a prescription for reducing inequality or achieving the long-term development objective of enabling individuals and groups to pursue their basic human needs. A romanticising of rural peasant life often underlies the liberal rhetoric in favour of land reform, and it is hard to believe that without a fundamental change in the social relations of production land reforms are not the panacea their adherents seem to believe.

The essence of development should be the creation of conditions in which individuals and groups can pursue their basic human needs, and development lies in releasing and mobilising creative energies of groups and individuals. Above all, this means that a basic needs strategy must involve widespread social and.economic participation in the development process. This in turn means that diverse forms of exploitation and domination must be tackled. To those who would regard such statements as revolutionary or radical, there should be a sharp retort that the pursuit of basic human needs is impossible without widespread participation, in local communities, in the workplace, in the national economy, and in the international economic community, where "dependency" has long precluded the effective pursuit of basic-needs development in a great many countries. To recommend policies that allow traditional forms of exploitation and domination to persist is implicitly to lend support to those social structures that are based on them.

\section{EMPLOYMENT AND VISIONS OF DEVELOPMENT}

"The hand is not only the organ of labour, it is also the product of labour." (Frederick Engels)

"There is no wealth but life." (John Ruskin)

For those who consider basic needs in the narrow sense by identifying core needs as targets for short-term and medium-term planning purposes, and for those who insist on analysing poverty and inequality only in terms of income and monetised wealth, employment has been regarded as little more than a means of satisfying the so-called basic needs. This conception stems from an essentially alienated vision of work, mistaking what is the lot of so many for the potential function of work, which is the development and extension of human personality, capacity, and potential. But however work is constituted, it influences behaviour and aspirations. Work and the division of labour determine the nature of needs, both quantitatively and qualitatively. As Marx wrote of the worker in general, "By thus acting on the external world and changing it, he at the same time changes his own nature" $[21$, p. 173].

Basically, there are two visions of development. The first and long dominant view is the enhancement of consumption and the belief that "consumption is the ultimate objective of all production" $[23$, p. 178]. This vision is actually founded on the principle of interminable dissatisfaction. As such, economic growth can be represented as the limitless and insatiable extension of the need to possess goods, through money, which in a remarkable phrase Marx saw as "the alienated ability of mankind" [22, p. 168]. Implicitly or explicitly, this has been recognised by writers of very diverse political persuasions, social scientists who have perceived that the capitalist economy functions on the basis of the creation of continued dissatisfaction with any standard of living, defined in terms of possession. Thus some neo-classical economists have analysed the process in terms of an increase in the "goods intensity of time use" and the increasing under-utilisation of commodities as a result. ${ }^{11}$ Perhaps the most enduring critique of this process is that of Thorstein Veblen who saw, though he certainly did not approve, modernization in terms of a shift from "vicarious leisure" to "vicarious consumption" [37]. But where needs are manipulated in the pursuit of profit, life tends to be measured in terms of status and possession.

In contrast, the second vision sees development more in terms of activity and the need to create conditions in which individuals can pursue their own "free needs" This perspective has tended to be submerged in the development literature, which has been dominated by the first vision, and as a result the nature of work has been largely ignored. The point may seem esoteric but is crucial for developing a more 
realistic and justifiable approach to the analysis of development strategies. Human history is distinguished by an unlimited capacity for imagination and invention, a creativity developed through the evolution of the human brain through action; in short, through work. As Bronowski superbly summarised the essence of human progress, unconsciously echoing Engels,

"The hand is the cutting edge of the mind. Civilisation is not a collection of finished artefacts, it is the elaboration of processes. In the end, the march of man is the refinement of the hand in action. The most powerful drive in the ascent of man is his pleasure in his own skill" $[4$, p. 116].

Yet, to put it mildly, the pleasure has been denied to the great majority. Work, as it has evolved in its specifically historical contexts, has degraded most of mankind, and thereby distorted perceived needs. As such, it has largely failed to extend human personality and creativity. But that does not mean that work per se should have such negative connotations. Conceptually it is not relevant that for the great majority work, if available at all, has involved demeaning, irksome drudgery. Much so-called education is irksome for the children, irrelevant to their perceived or actual needs, and inadequate in other respects - often merely grooming future workers and thus manifestly not emphasising aspects of education which would contribute to their creative and imaginative capacities. But that does not mean education is not crucial to the pursuit of human needs. Analogous arguments could be made with respect to health and doctors. ${ }^{12}$

Thus the more appropriate vision of a basic-needs strategy of development should be concerned with the nature of economic involvement - e.g. the division of labour, working conditions, and employment opportunities. When this is considered in detail, it seems that besides those conventionally recognised - generating income and output - there are six primary elements of economic participation that should be considered, elements which taken together raise serious questions about so-called basic-needs strategies that are couched in terms of employment generation without taking account of the nature of that employment. To give an example of a common approach, according to the Government of Pakistan the means by which they intend to reduce inequality and satisfy basic needs is by pursuing policies that maximise productive employment; this was the essence of their answer to the ILO's basic needs questionnaire sent out to governments in 1977 [17, p. 68]. Too often, references to quantitative employment requirements are not coupled with a consideration of qualitative dimensions or with the nature of labour relationships in general.

\section{WORK AND THE DIVISION OF LABOUR}

Though there are others, there are six key dimensions of labour-force activity which should form the nucleus of a basic-needs-oriented strategy of development.

${ }^{12}$ One reader of this paragraph contended that nobody is forced to be educated, whereas people are forced to work. Given compulsory school enrolment and the wide range of social and economic sanctions against those not attaining certain socially-determined levels of schooling, this contention is most unconvincing.
It is useful to consider these briefly, not as a means of suggesting some ideal blueprint but to help focus critical discussion on existing patterns of "development". The ultimate justification is a devastatingly modest one, that of encouraging the collection and dissemination of information that is both more relevant for analysing issues of poverty and inequality and is "mildly subversive" of existing forms and levels of exploitation and oppression. This latter, statistical issue will be considered in the following section.

The first of the six elements is the one which always should be kept in mind when less abstract considerations are receiving practical attention. The rhetorical question has been posed countless times through the ages, but perhaps never more poignantly than in a few memorable lines of Hamlet:

\section{"What is a man,}

If his chief good and market of his time

Be but to sleep and feed? A beast, no more.

Sure he that made us with such large discourse

Looking before and after, gave us not

That capability and God-like reason

To fust in us unus'd."

Work should provide the opportunity to develop and retain that sense of reason, that capability and creativity. "Better lack bread than lack life," cried D. H. Lawrence despairingly, fearing the misery "not of physical want but a far more deadly vital want". Planners and intellectuals almost certainly take account of this in their own careers, but typically regard such considerations as somewhat esoteric when analysing poverty and recommending policies for overcoming it. But recognising that the nature of work should be such as to allow the development of workers' capabilities and that it should increasingly satisfy psychological and physical needs has implications for the division and intensity of labour that would be compatible with a basic-needs strategy of development. And it implies that employment should facilitate the development of skills according to workers' capacities.

Emphasising that work should foster creativity is, of course, idealistic when faced by the grim reality of grinding poverty, but unless it is recognised that this is a desirable attribute of work, and that work is desirable as the means of extending human creativity and comprehension of reality, social and economic planners and labour force statistics will continue to ignore it. And that will only mean that analysts will continue to justify relegating the issues to footnotes, at best, on the grounds that there is no information and that the issues have been traditionally left aside.

In that connection, it is essential that employment opportunities should be compatible with the skills and capacities of workers. The word "compatible" is used guardedly here because of the danger that "manpower planning" - with its implications for data collection - may be taken as the pernicious practice of tailoring workers to the available jobs rather than developing the nature of work to suit the human requirements of workers. Too often, manpower planning has been used 
to determine the structure and level of output of educational institutions, almost to the extent of making secondary schooling an appendage of the production process. In any genuine basic-needs strategy of development that approach would surely be rejected. However, conversely, an approach which tailored jobs for the currently available workers is also dubious, if only because the nature and structure of jobs tend to reproduce a work force appropriate for them. Thus, if jobs were oriented to fit an unskilled, uneducated work force, there would be a tendency to fit workers into the mould of those jobs on a continuing basis; one likely consequence is that both planners and uneducated workers would be inclined to give low priority to education and training.

The best safeguard against either of these tendencies - though it is certainly not totally reliable - would seem to lie in the satisfaction of the second condition for effective economic participation, that of ensuring widespread involvement in economic decision-making. If a worker is merely required to produce what he or she is instructed to produce, economic participation takes an alienated form that is inconsistent with the pursuit of basic human needs. To assess the extent to which there is opportunity for active involvement in production and distribution, decisions probably cannot be done in an abstract way because forms of involvement can vary very widely. But as briefly argued in the next section, there are various indicators which could be used without difficulty for examining this issue

Thirdly, economic activity is potentially the main means of integrating individuals into society. To cut men and women off from social production is effectively to cut them off from social involvement, for the absence of the social interactions that should be associated with work activity must endanger and distort the individual's appreciation and comprehension of reality, as well as of social and economic changes taking place. Of course, in practice the organization of most work has failed in that respect and has failed miserably; the detailed and social division of labour in most societies has seen to that. But a necessary condition for social integration is the existence of work opportunities for all those wanting work. This means that unemployment in its various guises cannot be tolerated. In itself, involuntary unemployment not only tends to result in the denial of the means of satisfying consumption needs, but induces a deterioration in physical and mental energy, can and in most cases probably does lead to a sense of shame and incapacity, and reduces the individual's social status. But the question of social integration also has implications for the nature of work, making certain kinds of isolated, subordinated labour incompatible with the pursuit of human needs.

Fourthly, economic participation must be compatible with the enjoyment of leisure. This means that there must be a trend towards an equitable distribution of work, so that all groups have the opportunity of enjoying leisure. It also means that the work should not sap the mental and physical energies of workers to the extent that they cannot make use of the time available for leisure pursuits. Moreover, work should be an avenue for obtaining leisure, so that the conventional dichotomy of work and leisure should be replaced as far as possible by an integration of leisure and work in a common life activity.

The fifth aspect of work - and in many countries it is clearly the one demanding the most immediate attention - is that it should not jeopardise mental or physical health of the workers or their families. Clearly, many forms of work seriously violate that condition. ${ }^{13}$ A corollary is that, ideally, work should improve the health and mental capacities of workers directly. Thus, social planners should be concerned with evaluating the effect of certain types of work on health, and with the need to reduce the "drudgery" content of work and the extent of overwork.

Finally, the sixth element of work is that it should entail an extending amount of security. The unemployed are most likely to suffer from chronic insecurity, but many of those employed are also likely to experience it, particularly those forced to work as casual labourers or as bonded labour. All workers, whether peasants or wage workers or salaried employees, should be protected against economic insecurity, or should be able to choose whether or not to be protected. At the very least, this implies extremely low rates of unemployment, security of employment, and access to the means of production and earnings that are reliable. ${ }^{14}$ It also implies a need for present security for the future.

To sum up, socially productive activity is an essential human activity. As such, economic participation, ideally, should satisfy six conditions - the provision of adequate income-earning opportunities, the provision of conditions of security and protection, the avoidance of drudgery and overwork, the allowance of leisure, the opportunity for active involvement in production decision-making, and the development of work compatible with the needs and capacities of the workers.

\section{INDICATORS OF EMPLOYMENT FOR BASIC NEEDS DEVELOPMENT PLANNING}

Conventional labour force data have been geared to the needs of economic planning concerned primarily with economic growth and the implied manpower requirements. It has been implicitly assumed that what is required is information on the level of employment and the number of workers available for employment, in each case typically disaggregated by broad occupational and industrial classifications. With a common emphasis on skill, tabulations typically have been presented giving employment and unemployment information by schooling, age, and sex. Now the question is whether this type of information is adequate for development planning that is oriented more explicitly to the welfare or basic needs of the population.

${ }^{13}$ For a discussion of some of the issues involved in this respect, see [33, Chapter 4]. There it is argued that the shift to wage labour has typically made the relationship between work and health far more fragile.

${ }^{14}$ The "acceptable" unemployment would presumably be what is commonly described as frictional unemployment, though such concepts open up a host of methodological problems. 
It seems evident that that sort of data are not adequate; but the data that are required depend on how employment is related to basic needs. Those who argue that employment is merely a necessary means towards the end of higher living standards are likely to want a narrower set of labour force data than those who feel it is impossible to separate means from ends and that there are elements of work which are integral aspects of any basic-needs strategy.

There are three major issues which have to be considered if planners and statisticians are to have a framework with which to collect appropriate labour force data The first is the need to place data requirements in the context of the structure of production and distribution. The second is the need to unravel the relationships between social and individual welfare and labour force involvement. The third is the need to devise a practicable framework for the collection and presentation of labour data. If it is accepted that a basic-needs strategy should be geared to overcome inequalities based on exploitation as well as absolute poverty, the sort of data collected should be fundamentally concerned with distributional issues and with highlighting group- and class-specific differences in living standards and socio-economic position. To do this effectively means that the data collection should reflect an analysis of the structure of production and the patterns of change taking place.

Statisticians and social scientists all too easily regard data collection as scientifically neutral, whereas, of course, it reflects assumptions, prejudices, and political views. In practice, most statistical offices have based their data-collecting programme on what have been collected traditionally. The relevance of this point can be better appreciated if it is recognised that the type of national income and labour force data now gathered with growing intensity and enthusiasm for "accuracy" in most countries of the world has been greatly influenced by the Keynesian model developed in the 1930's and 1940's, which has always been less concerned with the changing structure of production and distribution than with cyclical changes in investment, employment, and economic growth in industrialized countries. If the concern was more explicitly with transforming the structure and social relations of production and with reducing exploitation and its attendant deprivations, it would be very surprising indeed if the data requirements were the same or anything like the same.

Every society is based on an economic structure consisting of some combination of essentially conflicting modes of production. The principal modes that have been identified have been what have been called primitive subsistence, feudal, capitalist, co-operativist, and socialist. While there are familiar disagreements on classifying and characterising these different modes of production, it is quite clear that there are meaningful distinctions to be made and that to start by ignoring or grossly simplifying such analytical distinctions is to commit the Myrdalian sin of misaggregation, which must restrict effective analysis and planning. In that context, the desired data should illuminate the process by which the income or economic surplus is distributed between the actual producers and other groups within each economic sector. Only by this means can data show the extent to which certain groups are de- prived of income and welfare, mechanisms by which this pattern of deprivation occurs, and the changing pattern of deprivation corresponding to the changing structure of production.

Now I do not want to get any further into the complexities of this very complex paradigm - in any case it would be hard to do so in the abstract - but this perspective is a means of making one simple but crucial point. That is that the type of labour force or other data required depends on the mode of production and distribution one is considering; the criteria by which the performance of the mode should be assessed will be quite different in the case of, say, the feudal (landlord-peasant) mode than in that of the capitalist (capitalist-wage worker) mode of production. In the former, data should indicate the nature of the income, its insecurity or fluctuation, the pattern and extent of visible or concealed deductions from that income, the nature of tenancy agreements and land tenure, the array of labour and other conventional obligations, the precariousness of paternalistic employment relationships, and so forth. For the capitalist mode, information is required on the form and reliability of the wage, the worker's obligations associated with wage labour, the intensity and duration of wage labour, the rate of labour turnover and the reasons for it, and opportunities for skill, occupational, and socio-economic mobility. ${ }^{15}$ Not only is the required information likely to be different, but getting data for each of the groups in each mode of production would enable planners and analysts to identify the target (dispossessed or relatively deprived) groups more precisely than could be done if the data were presented in aggregate form. In that connection, disaggregations by such demographic characteristics as age and sex, or even by rural-urban residence, are by themselves unlikely to be analytically very enlightening. In sum, data on any aspect of welfare - any secial indicator - should be based on prior consideration of the aggregation procedure to be followed. And that means quite simply that we have to relate social indicators to the structure and social relations of production.

For all the six elements of economic activity identified earlier, some proxy or set of proxy indicators is required, and there is no reason for them to correspond to the conventional labour force information collected in Pakistan or in most other countries. ${ }^{16}$ The chosen indicators should be related to the structure of production and distribution which means, inter alia, the data should be disaggregated according to identifiable groups in the production system. It should also be accepted that the selection of indicators is necessarily and unavoidably "normative", precisely because the choice is determined by the social scientists' paradigm or vision of the world. ${ }^{17}$

${ }^{15}$ Socio-economic mobility encompasses opportunities for increasing status and control within the production process as well as income.

${ }^{16}$ For an analysis of labour force data in Pakistan, see [30, pp. $15-51$ and pp. $52-56$ ] 7 Thus in most low-income countries the set of socio-economic indicators should almost certainly start with some measure of the dependency status of the economy in question, some index or indices of national self-reliance. For a brief discussion, see [34, pp. $3-5]$. 
A vast amount of work has recently been done on labour force concepts and an array of alternative methodologies has been suggested; but for the most part these have been refinements of what is commonly described as the "labour force approach". ${ }^{18}$ There have been few if any attempts to present a broader approach that would take account of all or most of the six elements of economic participation relevant to social development.

The first aspect of labour force data is that they should identify the principal labour relationships. Conventional data divide up the labour force by employment status - employers, own account workers, wage workers, and unpaid family workers - but in most contexts such a categorization grossly oversimplifies reality. The landlord and the dependent peasant are concealed, and the ideological sleight of hand means that the mechanisms of exploitation and inequality are also concealed. Statistics are required on the nature of the deductions from income or produce, the extent of those deductions, and the obligations attendant on having a specific work status. And a survey of a village economy should ascertain information on how much time tenants have to work for the landlord, what proportion of their income has to go to pay interest to usurious moneylenders, or what proportion of the crop has to go to the landlord or middleman. Data collection oriented to basic needs that neglected such issues in rural areas of South and South-East Asia, or in many other parts of the world for that matter, would have little value.

The required labour data should strongly emphasise health and energy implications of the pattern of work. Again, a vast amount has been written on measuring "under-employment" but remarkably little on what could be described as "overemployment". Indices of the latter would vary according to the economic and social environment, but would include the proportion of the workers obliged to work long working days, the reasons for that and particularly the social relations underlying it, the proportion doing heavy manual labour, and the proportion enforced by low incomes to continue an existence of occupational multiplicity. There should also be measures of calorie-protein needs of specific jobs; the FAO have done useful work in this area, estimating the dietary (calorie) needs of different categories of workers in various environments $[7 ; 8]$. Those needs should be related to the diet physically and financially available to the workers, given their income. Other relevant indicators would include measures of accidents in work and work-induced sickness, suitably disaggregated by socio-economic groupings.

Employment indicators of social integration would include the rate of unemployment and measures of involuntary "underemployment" and disguised employment, all disaggregated by socio-economic strata identified as having distinguishable roles in the production and distribution process. Such facets of labour force activity have received a relatively large amount of analytical attention, but in labour force statistics the relative attention given to these phenomena depends on the issues of concern to planners. Thus, if measuring immediate availability of workers for wage employment was the primary objective of the labour force statisticians, there might be less information on the disguised or "passively" unemployed - the discouraged job seekers - than if the concern was with the extent of involuntary isolation from the productive process due to the unavailability of appropriate opportunities. Data also should be provided on duration of unemployment and, highlighting institutional aspects, there should be indicators of the efficiency of labour market instruments for slotting workers into jobs. Even more importantly, there should be measures of the barriers to labour force entry by various groups - the most notable being women, whose labour force participation rate in high-income economic activity is surely one good index of the social integration of the population. But many analysts have referred to various other types of "discrimination" in the labour process; indicators of these phenomena should be developed and present ed in labour force reports, a proposition that has scarcely been attempted.

Besides social integration, there has been a systematic neglect of indicators that reflect the extent to which the pattern of economic activity allows work creativity and the development of skills, responsibilities, and "self-reliance". Every social scientist has a bag of epithets for demeaning and dehumanising work; yet, by the beginning of 1980 labour force data all over the world still failed to include any information related either to levels or trends in this facet of work activity.

In this respect the focus should be on the social and detailed division of labour. It is an apt aphorism that while the social division of labour divides society, the detailed division of labour divides the worker. The former arises when certain groups are restricted to a narrow range of jobs in which, once workers have entered them, there is little or no mobility between job-related strata. The detailed division of labour refers to the extent to which skills and productive labour are broken down into separate jobs. In that context, desirable labour force indicators include such measures as the proportion of workers doing jobs that are narrow in terms of skill use and in terms of the opportunity for skill development, enhanced responsibilities, or work autonomy. It should not be beyond the wit of labour statisticians to derive measures of the extent and incidence of upward (and downward) job mobility and the extent of opportunities for broadening work tasks, skills, and responsibilities, as well as the time typically required to do so. A basic-needs strategy of human development would presumably entail a broadening of jobs and an increase in the flexibility of workers and jobs. The search for appropriate information is a powerful means of highlighting the extent to which these objectives are not pursued. Then again, in most countries there should be statistics on the proportion of workers doing machine-paced labour as well as jobs that give little or no scope for flexible work

${ }^{18}$ For a review of these approaches and a critique, see [33, Chapter 2]. 
schedules; and there should be some "mismatch" indicators, such as the proportion of workers doing work below their skill capacity. ${ }^{19}$

To stress the potential creativity in work does not mean creative leisure should be neglected in labour force data. Leisure should be distinguished from non-work time; if as a direct result of the intensity of work two hours of the day have to be spent on recuperation, it is scarcely justifiable to describe those hours as leisure. Data on average hours of work on a group-specific basis are essential as proxy measures of the opportunity for leisure, but some indicators of the intensity of work in those hours and days are required, work-intensity being a particularly hard issue to translate into statistical concepts. Data should also reveal information on the distribution of work time between and within groups.

Indicators of involvement in economic decision-making are also underdeveloped. As noted earlier, an assessment of the extent to which the need for active involvement is met cannot be made in an abstract way because the form of involvement can vary very widely. Individual indicators can be applied, but it is essential that their use does not mean some resultant classification that effectively ignores alternative forms of work organization which might be preferable. For instance, it is sometimes suggested that the proportion of workers belonging to trade unions should be used as an indicator of economic involvement. However, whereas the union movement in many countries has had the function of protecting and enhancing the interests of workers, in others unions have been merely a convenient method of suppressing working-class protest and aspirations. So, by itself, union membership may be a misleading indicator. Other indicators are required to measure the extent of work autonomy, the degree of decentralisation of decision-making, the stability of jobs (labour turnover, etc.), lack of tension in labour relations (incidence of strikes, inter alia), and the extent of worker control of the production process. There is no need to pretend that this set of indicators could be translated easily into a set of statistics for planning and analysis, but to reiterate a point made earlier, unless we know what we want we will be forced to live with what we are given.

Finally, employment indicators that relate to aspects of security and protection are of both the "input" and "output" type. The former might include the proportion of rural workers with secure land tenure or having access to or ownership of other means of production, and the proportion of various groups of workers covered by pension schemes, maternity/paternity leave, sick leave and pay, opportunity to appeal to effective work tribunals, and perhaps redundancy pay. The latter would include, crucially, indices of involuntary labour turnover, landlessness among rural workers, and the proportion of workers having to rely on credit to continue production.

${ }^{19}$ The notion of mismatch has received attention in a number of South-East Asian countries in recent labour force studies, though the methodology adopted has been overly mechanistic. For a presentation of the general approach, see $[13$, pp. $65-75]$. For a critique, see $[33$, pp. $45-47]$.
The major aspects of work involvement which should receive attention do not map easily into a neat set of labour force statistics. However, while the above certainly does not provide an ideal framework for data collection, it does suggest a somewhat crude set of guidelines that are differently focused from the employment indices on which most growth-oriented planning is based.

\section{CONCLUDING REMARKS}

It is tempting to dismiss as secondary many of the more abstract considerations associated with the social relations of production because of the appalling misery associated with the denial of a few simple necessities of life such as food, shelter, and clothing. But this would be a very dubious path to follow for it can easily lead to a range of tyrannies, all rationalised in terms of "core material needs", from tyrannies of elitist minorities, firmly entrenched on the basis of a web of exploitative relationships, to tyrannies of the majority, in which the voices of dissent and often wisdom are stifled. If such eventualities are to be avoided, it is no use postponing fundamental issues arising from the social existence in which individuals and groups are expected to pursue their basic human needs. The key to human and social development is the set of social relationships on which production and distribution systems are erected, and the-focus of any development strategy that is genuinely concerned with human development should be the nature and division of labour. A strategy of development geared to basic human needs must concentrate primarily on removing the diverse social constraints to the pursuit of such needs. Any other approach is either Utopian or ultimately little more than an illusory palliative that gives a social status quo a greater chance of survival. Is that what the exponents of basic needs want?

\section{REFERENCES}

1. Adelman, I. "Redistribution before Growth: A Strategy for Developing Countries". Paper delivered at the 25th Anniversary of the Institute of Social Studies, The Hague, December 16 - 20, 1977.

2. Ahmad, N. Peasant Struggle in a Feudal Setting. Islamabad: Quaid-e-Azam University, Department of Economics. 1980.

3. Amjad, R. "Review of Past and Current Socio-Economic Development Plans and their Impact on Poverty". In Pakistan Manpower Institute, Employment Planning and Basic Needs in Pakistan - Report of a National Conference held at Islamabad, May 15-18, 1978. Islamabad. n.d.

4. Bronowski, I. The Ascent of Man. London: BBC. 1973.

5. Burki, S. J., N. Hicks and M. ul Haq. Pakistan: Operational Implications of Adopting Basic Needs Targets. Washington, D.C. : World Bank, Policy Planning and Program Review Department. December 1977. (Basic Needs Paper No. 4) 
6. Cassen, R. H. "Basic Needs: An Appraisal”. In IUSSP. Economic and Demographic Change. Helsinki. 1978.

7. FAO. Calorie Requirements. Rome. 1957.

8. FAO. Energy and Protein Requirements. Rome. 1973 (Report of a joint FAO/WHO ad hoc Expert Committee)

9. Gandhi Peace Foundation. National Survey on the Incidence of Bonded Labour: Preliminary Report. New Delhi: National Labour Institute. 1979.

10. Ghai, D. P., A. Khan, E. Lee and T. Alfthan. The Basic Needs Approach to Development: Some Issues Regarding Concepts and Methodology. Geneva: ILO. 1977.

11. Ghai, D. P., M. Godfrey and M. Lisk. Planning for Basic Needs in Kenya: Performance and Prospects. Geneva: ILO. 1979.

12. Griffin, K., and J. James. "Problems of Transition to Egalitarian Development". The Manchester School of Economics and Social Studies. Vol XLVII, No. 3. September 1979.

13. Hauser, P. M. "On the Measurement of Labour Utilisation for Manpower Policy”. International Technical Co-operative Centre Review. Vol. 3 , No. 11. July 1974.

14. IBRD. Rural Development: Sector Policy Paper. Washington, D.C. 1975.

15. ILO. Employment, Growth and Basic Needs: A One World Problem. Geneva. 1976.

16. ILO. Employment, Incomes and Equality: A Strategy for Increasing Productive Employment in Kenya. Geneva. 1972.

17. ILO. Follow-Up of the World Employment Conference: Basic Needs (Report VII). International Labour Conference, 65th Session 1979. Geneva. 1979.

18. King, R. Land Reform: A World Survey, London: Bell and Sons. 1977.

19. Lee, E. "Changing Approaches to Rural Development". International Labour Review. Vol. 119, No. 1. January-February 1980.

20. Linder, S. The Harried Leisure Class. New York: Columbia University Press. 1970.

21. Marx, Karl. Capital. Vol. 1. New York: New World Publishers. 1967.

22. Marx, K. The Economic and Philosophical Manuscripts of 1844 . London: Lawrence and Wishart. 1970.

23. Mehmet, O. Economic Planning and Social Justice in Developing Countries. London: Croom Helm. 1978.

24. Pearse, A. The Latin American Peasant. London: Frank Cass and Co. 1975.

25. Peek, P., and G. Standing. "Rural-Urban Migration and Government Policies in Low-Income Countries”. International Labour Review. Vol. 118, No. 6. November-December 1979.

26. Rawls, J. A Theory of Justice. Oxford: Oxford University Press. 1973.

27. Sahlins, M. Stone Age Economics. London: Tavistock Publications. 1974.
28. Scott, W. "Poverty Monitoring in Developing Countries". Development and Change. Vol. 10, No. 3. July 1979.

29. Selowsky, M. Balancing Trickledown and Basic Needs Strategies: Income Distribution Issues in Large Middle-Income Countries with Special Reference to Latin America. Washington, D.C.: IBRD. June 1979. (World Bank Staff Working Paper No. 335)

30. Shah, Makhdoom A., and Zeba Sathar. "Quantification of Unemployment and Underemployment in Pakistan: Problems of Conceptualisation and Measurement". In Pakistan Manpower Institute, Employment Planning and Basic Needs in Pakistan - Report of a National Conference held at Islamabad, May 15 - 18, 1978. Islamabad. n.d.

31. Sheehan, G., and M. Hopkins. Basic Needs Performance: An Analysis of Some International Data. Geneva: ILO. 1979.

32. Srinivasan, T. N. "Development, Poverty and Basic Human Needs: Some Issues”. Food Research Institute Studies. Vol. XVI, No. 2. 1977.

33. Standing, G. Labour Force Participation and Development. Geneva: ILO. 1978 .

34. Standing, G. Socialism and Basic Needs in Guyana. Geneva: ILO. 1977. (Population and Employment Working Paper No. 61)

35. Standing, G., and R. Szal. Poverty and Basic Needs. Geneva: ILO. 1979

36. Streeten, P. P. "Basic Needs: Premises and Promises". Journal of Policy Modelling. Vol. 1, No. 1. January 1979.

37. Veblen, T. The Theory of the Leisure Class: An Economic Study of Institutions. London: Unwin Books. 1970. (First published in 1899) 